\title{
PENGARUH KEPUASAN KERJA, KUALITAS KEHIDUPAN KERJA DAN PRESTASI KERJA TERHADAP KINERJA GURU DI MTS AL JAMIYATUL WASLIYAH TEMBUNG
}

\author{
${ }^{1}$ Muhammad Ihsan, ${ }^{2}$ Syukril Jamil Harahap, ${ }^{3}$ Husniati, ${ }^{4}$ Dayatullah, ${ }^{5}$ Masrida \\ 1,2,3,4,5 Universitas Islam Sumatera Utara \\ Imhd.ihsan@gmail.com, ${ }^{2}$ syukkril.jammil@gmail.com, ${ }^{3}$ husniati.mm@gmail.com, ${ }^{4}$ dayatullah.mm@gmail.com, \\ 5 masrida.mm@gmail.com
}

\begin{abstract}
The formulation in this study is how the influence ofjob satisfaction,quality of work life and work achievement on teacher performance. The purpose of this study was to find out and analyze the effect ofjob satisfaction, quality of work life and work achievement on teacher performance. This research is a descriptive quantitative research. Data collection techniques are carried out through interviews, lists of questions and documentation studies. The sample in this study was 67 teachers. Variables are measured on a Likert scale. Hypothesis testing using multiple linear regression analysis through $F$ test and $t$ test.Simultaneous test results showed that job satisfaction, work quality and work achievement had a significant effect on teacher performance variables. In part, job satisfaction has a positive and significant effecton teacher performance, quality of work life has a positive and significant effecton teacher performance and work achievement has a positive and significant effect on teacher performance.
\end{abstract}

Keywords: Job Satisfaction, Quality of WorkLife., WorkAchievement, Performance

ABSTRAK : Rumusan pada penelitian ini adalah bagaimana pengaruh kepuasan kerja, kualitas kehidupan kerja dan prestasi kerja terhadap kinerja guru. Tujuan penelitian ini adalah untuk mengetahui dan menganalisis pengaruh kepuasan kerja, kualitas kehidupan kerja dan prestasi kerja terhadap kinerja guru. Penelitian ini merupakan penelitian deskriptif kuantitatif. Teknik pengumpulan data dilakukan melalui wawancara, daftar pertanyaan dan studi dokumentasi. Sampel dalam penelitian ini sebanyak 67 orang guru. Variabel diukur dengan skala Likert. Pengujian hipotesis menggunakan analisis regresi linear berganda melalui uji $F$ dan uji t. Hasil uji secara serempak menunjukkan bahwa kepuasan kerja, kualitas kehidupan kerja dan prestasi kerja berpengaruh signifikan terhadap variabel kinerja guru. Secara parsial, kepuasan kerja berpengaruh positif dan signifikan terhadap kinerja guru, kualitas kehidupan kerja berpengaruh positif dan signifikan terhadap kinerja guru dan prestasi kerja berpengaruh positif dan signifikan terhadap kinerja guru.

Kata kunci : Kepuasan Kerja, Kualitas Kehidupan Kerja, Prestasi Kerja, Kinerja.

\section{Pendahuluan}

Kinerja guru merupakan elemen penting dalam pendidikan, selain itu juga merupakan penentu tinggi rendahnya kualitas pendidikan. Kinerja gurudilakukan oleh gurudalam melaksanakan tugas seorang guru sebagai pendidik. Kualitas kinerja guru sangat menentukan pada kualitas hasil pendidikan dikarenakan guru merupakan sosok yang paling sering berinteraksi secara langsung dengan siswa pada saat proses pembelajaran.

Guru merupakan komponen penting dalam dunia pendidikan,oleh karenanya perhatian yang lebih perlu diberikan agar dapat menciptakan guru yang berkualitas sehingga hal tersebut dapat menunjang kinerja guru. Guru juga memegang peran penting dalam dunia pendidikan khususnya dalam bidang formal disekolah, guru sangat menentukan keberhasilan peserta didik terutama dalam hal proses belajar mengajar yang biasa dilaksanakan di sekolah.

Keberhasilan kinerja yang ditunjukan guru dipengaruhi oleh lingkungan sekitarnya.Oleh karena itu lingkungan sekitar khususnya dalam hal ini pihak sekolah semisal kepala sekolah yang mampu memotivasi serta 
memberdayakan guru agar tercipta kinerja yang baik serta mampuberperan sebagai guru yang professional disamping guru itu sendiri yang mampu meningkatkan kualitas kerjanya sendiri. Menurut Siagian (2013:45), kinerja dipengaruhi oleh beberapa faktor diantaranya: lingkungan kerja, budaya organisasi, kepemimpinan dan motivasi kerja, disiplin kerja, gaji, kepuasan kerja dan faktor-faktor lainnya.

Bagaimana suasana kelas berlangsung merupakan hasil dari kerja guru. Suasana kelas dapat "hidup", belajar tekun tetapi tidak merasa terkekang, atau sebaliknya, suasana kelas "suram", siswa kurang bersemangat dan diliputi rasa "takut", itu semua akibat dari hasil pemikiran dan upaya guru. (Suharsimi, 2009: 141)

Dengan demikian guru memiliki peran penting dalam mengelola kondisi kelas guna mencapai tujuan yang ingin dicapai. Kegiatan pembelajaran, dan hasil belajar peserta didik tidak saja ditentukan oleh manajemen sekolah, kurikulum, sarana dan prasarana pembelajaran, tetapi sebagian besar ditentukan oleh guru. Baik dan jeleknya prestasi siswa tergantung dari kinerja guru (Yamin dkk,2010:23).

Keberhasilan guru dalam proses pembelajaran sangat ditentukan kinerja guru sebagai pendidik. Kinerja guru merupakan kemampuan seorang guru dalam melaksanakan tugas pembelajaran di sekolah dan bertanggung jawab atas peserta didik di bawah bimbingannya dengan meningkatkan prestasi belajar peserta didik.

Yamin dkk (2010:23), mengemukakan definisi kinerja guru sebagai perilaku atau respon yang memberikan hasil yang mengacu kepada apa yang mereka kerjakan ketika dia menghadapi suatu tugas. Kinerja seorang guru akan tampak pada situasi dan kondisi kerja sehari-hari. Kinerja dapat dilihat dalam aspek kegiatan menjalankan tugas dan kualitas dalam menjalankan tugas tersebut.

Dengan memandang tugas utama seorang guru adalah mengajar, maka kinerja guru dapat terlihat pada kegiatan guru saat mengajar pada proses pembelajaran. Sedangkan

Depdiknas Tahun 2008 tentang Pengembangan Bahan Ajar dan Media, menyatakan Kinerja guru adalah kemampuan dan usaha guru untuk melaksanakan tugas pembelajaran sebaik-baiknya dalam perencanaan program pengajaran, pelaksanaan kegiatan pembelajaran dan evaluasi basil pembelajaran.

Berdasarkan basil pra penelitian yang peneliti lakukan di Mts Al Jamiyatul Wasliyah Tembung, sebagian guru sudah menunjukkan kinerja yang baik dalam menjalankan tugas dan fungsinya, akan tetapi masih ada sebagian kinerja guru yang rendah antara lain: masih terdapat guru yang mengajar secara monoton tanpa adanya inovasi pembelajaran, masih ada guru yang terlambat masuk kelas dan keluar kelas sebelum jadwal pergantian jam pelajaran, dan masih terdapat guru yang tidak memiliki persiapan yang matang atau kurangnya penguasaan terhadap materi ajar sehingga hanya sekedar menyampaikan materi.

Peran guru semakin penting dalam peningkatan di dunia pendidikan,maka perlu juga agar guru mendapatkan kepuasan kerjanya sehingga hal tersebut akan berdampak baik bagi prestasi kerja,displin kerja dan kualitas kerja sehinggga akan menjadikan kinerja guru menjadi lebih baik.

Penelitian terhadap kepuasan kerja menjadi penting dalam suatu lembaga pendidikan, karena diyakini bahwa kepuasan kerja yang tinggi akan mendorong peningkatan kinerja individu dan kelompok, yang pada gilirannya akan meningkatkan efektifitas organisasi secara keseluruhan. Studi kepuasan kerja dewasa ini menjadi perhatian yang serius dari para pimpinan lembaga pendidikan, karena berkaitan erat dengan tenaga kerja, produktivitas kerja dan kelangsungan hidup lembaga pendidikan yang bersangkutan. Kepuasan kerja merupakan hal yang bersifat individu dan akan mengalami tingkat kepuasan yang berbeda-beda sesuai dengan nilai-nilai yang berlaku pada diri masing-masing individu. Semakin banyak aspek-aspek pekerjaan yang sesuai dengan keinginan individu tersebut maka semakin tinggi tingkat kepuasan yang dirasakan individu dan sebaliknya.

Mangkunegara (2011:117) mendefinisikan kepuasan kerja adalah suatu perasaan yang mendukung atau tidak mendukung diri pegawai yang berhubungan dengan pekerjaannya maupun kondisi dirinya. Kepuasan kerja 
merupakan cerminan dari perasaan pekerja terhadap pekerjaannya. Hal ini tampak dalam sikap positif pekerja terhadap pekerjaan yang dihadapi dan lingkungannya. Sebaliknya, pegawai yang tidak puas akan bersikap negatif terhadap pekerjaan dan lingkungannya dalam bentuk yang berbeda-beda satu dengan yang lainnya. Adanya ketidakpuasan kerja pegawai seharusnya dapat dideteksi oleh organisasi.

Menurut Greenberg dan Baron dalam Charitin Devi dkk (2018) ada 2 (dua) teori pendekatan mengenai kepuasan kerja, yakni; (1) Two-factor Theory, Sebuah teori kepuasan kerja yang menggambarkan kepuasan dan ketidakpuasan berasal dari kelompok variabel yang berbeda yakni hygiene factors dan motivators. Hygiene factors adalah ketidakpuasan kerja yang disebabkan oleh sebuah kumpulan perbedaan dari faktorfaktor (kualitas pengawasan, lingkungan kerja, pembayaran gaji, keamanan, kualitas lembaga, hubungan kerja dan kebijakan perusahaan). Karena faktor-faktor ini bersifat mencegah reaksi negative maka disebut sebagai hygiene (maintenance) faktor. Kepuasan kerja yang didatangkan dari sekumpulan faktor- faktor yang berhubungan pekerjaannya atau hasil secara langsung dari pekerjaannya (peluang promosi, pengakuan, tanggung jawab, prestasi) disebut sebagai motivators, karena merupakan level tertinggi dari kepuasan kerja. (2) Value Theory Sebuah teori kepuasan kerja yang bergantung pada kesesuaian antara hasil pekerjaan yang diperolehnya (penghargaan) dengan persepsi mengenai ketersediannya beberapa hasil. Semakin banyak hasil yang diperoleh maka ia akan lebih puas, jika memperoleh hasil yang sedikit maka ia akan lebih sedikit puas. Teori ini berfokus pada banyak hasil yang diperoleh. Kunci kepuasannya adalah kesesuaian hasil yang diterima dengan persepsi mereka.

Berdasarkan kedua teori tersebut maka dapat disimpulkan pendekatan dan pengukuran terhadap kepuasan kerja dilihat dari sisi faktor kepuasan yang berhubungan dengan hasil pekerjaan yang dicapai (peluang promosi dan prestasi) dan faktor yang yang datang dari luar yang mempengaruhi kepuasan dan ketidakpuasan (pengawasan, kebijakan perusahaan, lingkungan kerja dan upah)..

Hasil observasi yang dilakukan di Mts Al Jamiyatul Wasliyah Tembung, diperoleh beberapa fenomena yang menunjukkan rendahnya tingkat kepuasan kerja yang dirasakan oleh setiap guru antara lain ialah sistem imbalan yang ada dan pemberian tunjangan fungsional belum cukup memadai, atasan yang bersikap kurang perhatian dan kurang memberi pujian serta kurang mendengar pendapat dari bawahan, dan kurang terjalinnya komunikasi yang harmonis antar sesama rekan kerja.

Konsep k:ualitas kehidupan kerja menurut Cascio dalam Dwi Astrid Avianti dan Lindawati Kartika (2017:7), menjadi dua pandangan, pandangan pertama menyebutkan bahwa k:ualitas kehidupan kerja, sekumpulan keadaan dan praktik dan tujuan organisasi (contohnya: memperkaya pekerjaan, kebijakan promosi dari dalam, penyeliaan yang demokratis, partisipasi pegawai dan kondisi kerja yang aman). Sedangkan, pada pandangan kedua mendefenisikan kualitas kehidupan kerja sebagai persepsi pegawai seperti bahwa pegawai merasa aman, secara relatif merasa puas dan mendapatkan kesempatan untuk tumbuh dan berkembang seperti layaknya manusia.

Adanya k:ualitas kehidupan kerja juga menumbuhkan keinginan guru untuk tetap tinggal dalam lembaga pendidikan tempat ia bekerja. Performa lembaga pendidikan yang menurun akibat k:urang optimalnya k:ualitas kehidupan kerja, yang pada akhirnya akan menurunkan kualitas pekerjaan dalam lembaga pendidikan yang bermuara pada memburuknya k:ualitas pelayanan. Kurang optimalnya k:ualitas kehidupan kerja berdasarkan hasil observasi di Mts Al Jamiyatul Wasliyah Tembung, ditemukan fenomena masih adanya guru yang merasa tidak mempunyai kesempatan dalam mengembangkan keterampilan dan pengetahuan yang dimiliki, guru tidak diberi kesempatan untuk berpartisipasi atau terlibat dalam pengambilan keputusan pekerjaan, serta guru merasa lingkungan kerja yang kurang kondusif dan imbalan belum memenuhi standar hidup

Kualitas kehidupan kerja dipandang mampu untuk meningkatkan peran serta dan sumbangan para guru terhadap organisasi dengan keinginan agar guru diperlak:ukan sebagai individu yang dihargai di tempat kerja. prestasi kerja yang bagus akan dihasilkan guru jika mereka dihargai dan diperlakukan seperti layaknya manusia dewasa. 
Prestasi kerja merupakan hal yang sangat penting dalam lembaga pendidikan untuk mencapai tujuannya, sehingga lembaga pendidikan melakukan berbagai usaha untuk meningkatkannya. Prestasi dalam bekerja merupakan salah satu kebutuhan yang ingin dicapai setiap orang dalam bekerja. Prestasi kerja setiap guru tidak sama hasilnya, hal ini disebabkan karena setiap guru mempunyai kemampuan dan kemauan yang berbeda untuk melaksanakan pekerjaan.

Hasibuan (2016:94) mengatakan bahwa, prestasi kerja adalah suatu hasil kerja yang dicapai seseorang dalam melaksanakan tugastugas yang dibebankan kepadanya yang didasarkan atas kecakapan, pengalaman dan kesungguhan serta waktu. Prestasi kerja sangat penting bagi sebuah lembaga pendidikan untuk mencapai tujuannya, hal ini dikarenakan setiap lembaga pendidikan pada dasarnya didirikan untuk mendapatkan keuntungan sebesarbesarnya. Lembaga pendidikan harus dapat mempergunakan sumber daya manusianya semaksimal mungkin, dalam hal ini guru yang tersedia untuk mencapai tujuan tersebut.

Prestasi kerja guru dalam suatu lembaga pendidikan menempati posisi strategis, karena prestasi kerja guru yang baik dapat menjadi pendorong untuk mencapai tujuan lembaga pendidikan. Sebaliknya, prestasi kerja guru yang buruk dapat menjadi penghambat dalam usaha pencapaian tujuan lembaga pendidikan Pada kenyataannya, prestasi kerja yang dimiliki tidak sesuai harapan suatu lembaga pendidikan, dan masih menemui prestasi kerja yang rendah. Akibat dari prestasi kerja yang rendah, maka berdampak pada produktivitas lembaga pendidikan menurun dan tidak dapat memenuhi target yang telah ditetapkan, menderita kerugian dan mengalami hambatan dalam perkembangannya. Sedangkan bagi yang memiliki prestasi kerja yang rendah, akan menghambat perkembangan karir dan pendapatan.

Prestasi kerja menurun rm ditemui di Mts Al Jamiyatul Wasliyah Tembung yang memiliki vrsi "Terbentuknya Insan Kamil Yang Beriman, Berakhlaqul Karimah, Berilmu, Ramah Dan Peduli Lingkungan Dalam Mencapai Kebahagian Dunia Dan Akhirat" menilai prestasi kerja guru masih tidak memenuhi harapan dan tujuan yang telah ditetapkan. Berdasarkan hasil wawancara yang telah dilakukan, ditemukan beberapa fenomena yang terjadi terkait penurunan prestasi kerja antara lain masih terdapat guru yang seringkali mengulur-ulur waktu dalam bekerja dan tingkat absensi yang rendah, kurangnya pengetahuan pekerjaan dan inisiatif yang dimiliki guru dalam melaksanakan pekerjaan, kurangnya kecekatan mental dan keterampilan kerja guru serta kurang maksimalnya hasil kerja dan rasa tanggung jawab dalam menyelesaikan pekerjaan.

Prestasi kerja merupakan kualitas dan kuantitas dari suatu hasil kerja (output) individu maupun kelompok dalam suatu aktivitas tertentu yang diakibatkan oleh kemampuan alami atau kemampuan yang diperoleh dari proses belajar serta keinginan untuk berprestasi lebih baik. Prestasi kerja merupakan tingkat pelaksanaan kerja yang menunjukan hasil kerja sesuai dengan standar yang ada dalam suatu lembaga, organisasi, instansi maupun perusahaan. Prestasi kerja yang baik dapat memperlancar penggerak utama seluruh kegiatan dalam mencapai tujuan, yaitu untuk mempertahankan kelangsungan hidup maupun untuk memperoleh keuntungan. Berhasil tidaknya suatu lembaga, organisasi, instansi maupun perusahaan dalam mempertahankan eksistensinya dimulai dari usaha manusia itu sendiri dalam melaksanakan pekerjaannya secara maksimal.

\subsection{Rumusan Masalah}

Berdasarkan masalah tersebut, maka penulis merumuskan masalah sebagai berikut:

1) Bagaimana pengaruh kepuasan kerja terhadap kinerja guru di Mts $\mathrm{Al}$ Jamiyatul Wasliyah Tembung.

2) Bagaimana pengaruh kualitas kehidupan kerja terhadap kinerja guru di Mts Al Jamiyatul Wasliyah Tembung.

3) Bagaimana pengaruh prestasi kerja terhadap kinerja guru di Mts Al Jamiyatul Wasliyah Tembung.

4.) Bagaimana pengaruh kepuasan kerja, kualitas kehidupan kerja dan prestasi kerja terhadap kinerja guru di Mts Al Jamiyatul Wasliyah Tembung.

\subsection{Batasan Masalah}

Untuk menghindari ruang lingkup permasalahan yang terlalu luas dan untuk memperjelas serta membatasi ruang lingkup permasalahan maka penulis membatasi pada 
masalah; Pengaruh Kepuasan Kerja, Kualitas Kehidupan Kerja Dan Prestasi Kerja Terhadap Kinerja Guru Di Mts Al Jamiyatul Wasliyah Tembung.

\subsection{Hipotesis}

Berdasarkan kerangka konsep penelitian diatas, maka hipotesis dalam penelitian ini adalah sebagai berikut:

1) Kepuasan kerja berpengaruh terhadap kinerja guru Di Mts Al Jamiyatul Wasliyah Tembung.

2) Kualitas kehidupan kerja berpengaruh terhadap kinerja guru di Mts Al Jamiyatul Wasliyah Tembung.

3) Prestasi kerja berpengaruh terhadap kinerja guru di Mts Al Jamiyatul Wasliyah Tembung.

4) Kepuasan kerja, kualitas kehidupan kerja, dan prestasi kerja berpengaruh terhadap kinerja guru di Mts Al Jamiyatul Wasliyah Tembung.

\subsection{Tujuan Penelitian}

Adapun yang menjadi tujuan dari penelitian ini adalah

1) Untuk mengetahui dan menganalisis pengaruh kepuasan kerja terhadap kinerja guru di Mts Al Jamiyatul Wasliyah Tembung.

2) Untuk mengetahui dan menganalisis pengaruh kualitas kehidupan kerja terhadap kinerja guru di Mts Al Jamiyatul Wasliyah Tembung.

3) Untuk mengetahui dan menganalisis pengaruh prestasi kerja terhadap kinerja guru di Mts Al Jamiyatul Wasliyah Tembung.

4) Untuk mengetahui dan menganalisis pengaruh kepuasan kerja, kualitas kehidupan kerja dan prestasi kerja terhadap kinerja guru di Mts Al Jamiyatul Wasliyah Tembung.

\section{Metode Penelitian \\ 2.1.Populasi}

Menurut Sugiyono (2011 :389) bahwa populasi adalah wilayah generalisasi terdiri dari objek atau subjek yang mempunyai kualitas dan karakteristik tertentu yang ditetapkan oleh peneliti kemudian ditarik kesimpulannya. Adapun populasi dalam penelitian ini adalah seluruh guru di Mts Al Jamiyatul Wasliyah Tembung yang berjumlah 67 orang.

\subsection{Sampel}

Pada penelitian ini, dilakukan penelitian pada sebagian dari populasi, yang disebut dengan penelitian sampel. Menurut Arikunto (2010: 109), cara pengambilan sampel untuk subyek yang kurang dari 100, lebih baik diambil semua sehingga penelitiannya merupakan penelitian populasi. Selanjutnya jika jumlah subyeknya besar dapat diambil antara $10-15 \%$, atau 20$25 \%$ atau lebih

Berdasarkan ketentuan tersebut, maka sampel dalam penelitian ini seluruh populasi (Total Population Sampling), sehingga sampel dalam penelitian ini sebanyak 67 orang..

\subsection{Uji Normalitas}

Uji normalitas bertujuan untuk menguji apakah residual model regresi yang diteliti berdistribusi mormal atau tidak. Dalam penelitian ini pengujian normalitas metode yang digunakan adalah UJl KolmogorovSmirnov dengan bantuan Program Statistical Product and Service Solution (SPSS) for Windows.

Tabel 1. Hasil Uji Kolmogorov Smirnov

One-Sample Kolmogorov-Smirnov Test

\begin{tabular}{|ll|l|}
\hline & & $\begin{array}{l}\text { Unstandardize } \\
\text { d Residual }\end{array}$ \\
\hline $\mathrm{N}$ & & 67 \\
Normal Parameters ${ }^{\mathrm{a}, \mathrm{b}}$ & Mean & $0 \mathrm{E}-7$ \\
& Std. Deviation & 1.98727783 \\
& Absolute & .088 \\
Most Extreme Differences Positive & .088 \\
& Negative & -.056 \\
Kolmogorov-Smirnov Z & & .720 \\
Asymp. Sig. (2-tailed) & .677 \\
\hline $\begin{array}{ll}\text { a. Test distribution is Normal. } \\
\text { b. Calculated from data. }\end{array}$
\end{tabular}


Tabel 1 diatas menunjukkan bahwa uji kolmogorov smirnov pada nilai residual pada baris Asymp. Sig. (2-tailed) menghasilkan nilai signifikansi sebesar $0,677>0.05$, berdasarkan hasil ini maka disimpulkan residual model regresi berdistribusi normal, dengan demikian asumsi normalitas residual telah terpenuhi dan data berdistribusi normal.

\subsection{Uji Multikoloniearitas}

Pengujian multikolinieritas bertujuan untuk mengetahui apakah antara variabel independen memiliki hubungan atau tidak satu sama lainnya. Uji multikolinieritas perlu dilakukan karena jumlah variabel independen dalam penelitian ini berjumlah lebih dari satu. Metode untuk menguji ada tidaknya multikolinearitas dapat dilihat Tolerance Value dan Inflation Factor (VIF). Batas tolerance value adalah 0,10 atau nilai VIF adalah 10. Jika tolerance value $>0,10$ dan VIF $<10$ maka tidak terjadi multikolinearitas dan sebaliknya jika tolerance value < 0, 10 dan VIF > 10 maka terjadi multiko linearitas. Hasil pengolahan dapat dilihat pada tabel 5.13 berikut ini:

Coefficients $^{\mathrm{a}}$

Tabel 2. Hasil Uji Multikolinearitas

\begin{tabular}{|ll|l|l|l|l|l|}
\hline \multicolumn{2}{|l|}{ Model } & \multicolumn{2}{|l|}{ Unstandardized Coefficients } & $\begin{array}{l}\text { Standardized } \\
\text { Coefficients }\end{array}$ & \multicolumn{2}{l|}{ Collinearity Statistics } \\
\cline { 3 - 7 } & & B & Std. Error & Beta & Tolerance & VIF \\
\hline \multirow{4}{*}{1} & Constant) & 4.163 & 4.577 & & & \\
& Kepuasan & .271 & .098 & .271 & .890 & 1.123 \\
& Kualitas & .283 & .135 & .197 & .977 & 1.024 \\
& Prestasi & .457 & .094 & .481 & .871 & 1.148 \\
\hline
\end{tabular}

a. Dependent Variable: Kinerja

Berdasarkan tabel 2 diatas, terlihat bahwa nilai tolerance dari seluruh variabel independen memiliki nilai tolerance value lebih besar dari 0,10 dan nilai VIF lebih kecil dari 10 maka dapat disimpulkan bahwa tidak terjadi multikolinieritas.

\subsection{Uji Heterekodasitas}

Uji heteroskedastisitas dilakukan untuk mengetahui apakah dalam sebuah model regresi terjadi kesamaan atau ketidaksamaan varians antara pengamatan satu dengan pengamatan lainnya. Jika varians dari residual dari suatu pengamatan ke pengamatan lain tetap disebut homoskedasitas dan apabila berbeda disebut dengan heteroskedastisitas. Suatu model regresi yang baik adalah suatu model yang tidak terjadi heteroskedatisitas.

Menganalisis data dalam pengujian asurnsi klasik mi, peneliti menggunakan Program Statistical Product and Service Solution (SPSS) for Windows dan dapat dilihat pada gambar 3 berikut:

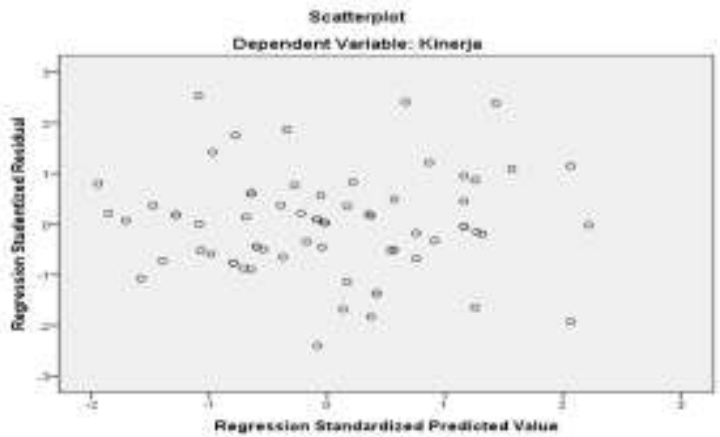

Gambar 1. Uji Heterokedasitas

Dari gambar di atas menunjukkan bahwa diagram pencar tidak membentuk suatu pola atau acak, dengan demikian dapat dikatakan bahwa regresi tidak mengalami gangguan heteroskedastisitas pada model regresi, dengan demikian asumsi tidak ada heteroskedastisitas telah terpenuhi.

\subsection{Uji Autokordasi}

Uji autokorelasi digunakan untuk mengetahui penyimpangan asumsi klasik autokorelasi yaitu korelasi yang terjadi antara residual pada satu pengamatan dengan pengamatan lain pada model regresi. Model regresi yang baik adalah tidak terdapat autokorelasi. Pendekatan yang digunakan 
untuk menguji ada atau tidaknya autokorelasi adalah Uji Durbin-Watson (DW test)

Uji Durbin-Watson hanya digunakan untuk autokorelasi tingkat satu (first order autocorrelation) dan mensyaratkan adanya intercept (kostanta) dalam model regresi dan tidak ada variabel lain diantara variabel independent.

Tabel 3. Hasil Uji Durbin-Watson (DW Test)

Model Summary ${ }^{\mathrm{b}}$

\begin{tabular}{|l|l|l|l|l|l|}
\hline Model & $\mathrm{R}$ & R Square & $\begin{array}{l}\text { Adjusted } \\
\text { Square }\end{array}$ & $\begin{array}{l}\text { Std. Error of } \\
\text { the Estimate }\end{array}$ & Durbin-Watson \\
\hline 1 & $.677^{\mathrm{a}}$ & .458 & .432 & 2.034 & 1.756 \\
\hline
\end{tabular}

a. Predictors: (Constant), Prestasi, Kualitas, Kepuasan

b. Dependent Variable: Kinerja

Berdasarkan tabel 3, diatas diperoleh nilai Durbin-Watson sebesar 1,756. Nilai Durbin-Watson menurut tabel dengan $\mathrm{n}=67$ responden dan $\mathrm{K}=3$ (dalam hal ini adalah jumlah variabel bebas) didapat angka $\mathrm{dl}=$ 1.512 dan $d u=1.698$. oleh karena itu nilai DW hitung > du $(1,756>1.658)$, maka dapat disimpulkan bahwa tidak terdapat autokorelasi dalam model regresi maka model layak untuk digunakan.

\section{Pengujian Hipotesis}

Pengujian hipotesis dapat dilakukan melalui pembuktian koefisien regresi. Pembuktian koefisieni regresi dilakukan untuk menguji pengaruh variabel bebas yaitu kepuasan kerja, kualitas kehidupan kerja dan prestasi kerja terhadap variable terikat yaitu kinerja. Pengujian hipotesis ini juga dilakukan secara simultan dengan menggunakan uji $\mathrm{F}$ maupun secara individual dengan menggunakan uji t.
Pengujian hipotesis secara simultan yang diajukan diterima atau ditolak, digunakan uji F dengan ketentuan jika Fhitung > F1abeI maka Ho ditolak dan $\mathrm{H}$, diterima, sebaliknya jika Fhitung :S FtabeI maka Ho diterima dan H1 ditolak. Sedangkan pengujian hipotesis secara individual yang diajukan diterima atau ditolak digunakan uji t dengan ketentuan jika thitung $>$ tlabeI maka Ho ditolak dan $\mathrm{H}$, diterima, sebaliknya jika 1hitung :S t1abeI maka Ho diterima dan $\mathrm{H}$, ditolak.

\subsection{Analisis Regresi Linier Berganda}

Analisis regresi linier berganda digunakan untuk mengetahui berapa besar pengaruh kepuasan kerja, kualitas kehidupan kerja dan prestasi kerja terhadap kinerja guru di Mts Al Jamiyatul Wasliyah Tembung. Analisis dilakukan dengan menggunakan bantuan SPSS dengan output sebagai berikut:

Coefficients $^{\mathrm{a}}$

Tabel 4. Hasil Uji Regresi Linear Berganda

\begin{tabular}{|ll|l|l|l|l|l|}
\hline \multicolumn{2}{|l|}{ Model } & \multicolumn{2}{|l|}{ Unstandardized Coefficients } & $\begin{array}{l}\text { Standardized } \\
\text { Coefficients }\end{array}$ & T & Sig. \\
\cline { 3 - 5 } & & B & Std. Error & Beta & & \\
\hline \multirow{4}{*}{1} & (Constant) & 4.163 & 4.577 & & .909 & .367 \\
& Kepuasan & .271 & .098 & .271 & 2.753 & .008 \\
& Kualitas & .283 & .135 & .197 & 2.101 & .040 \\
& Prestasi & .457 & .094 & .481 & 4.836 & .000 \\
\hline
\end{tabular}

a. Dependent Variable: Kinerja

Berdasarkan pengolahan data pada tabel 5.16 diatas terlihat output kolom kedua bagian B (Unstandardized Coefficients), diperoleh persamaan regresi linier berganda yaitu:

$$
y=a+\mathrm{b} 1 \times 1+b 2 \times 2+\mathrm{b} 3 \times 3+e
$$

$$
\begin{gathered}
\mathbf{Y}=\mathbf{4 , 1 6 3 + 0 , 2 7 1 X t}+\mathbf{0 , 2 8 3 X 2}+\mathbf{0 , 4 5 7} \mathrm{X} 3 \\
+E
\end{gathered}
$$

Dengan persamaan regresi linier berganda tersebut dapat dijelaskan 
1) Nilai konstanta adalah sebesar 4,163 hal ini menyatakan bahwa jika variable kepuasan kerja, kualitas kehidupan kerja dan prestasi kerja diabaikan, maka nilai kinerja sebesar 4, 163.

2) Koefisien regresi untuk variabel kepuasan kerja sebesar 0,271, hal ini menunjukkan bahwa setiap kenaikan 1 \% faktor kepuasan kerja maka akan meningkatkan kinerja sebesar $27,1 \%$.

3) Koefisien regresi untuk variabel kualitas kehidupan kerja sebesar 0,283, hal ini menunjukkan bahwa setiap kenaikan 1 $\%$ faktor kualitas kehidupan kerja maka akan meningkatkan kinerja sebesar 28,3\%

4) Koefisien regresi untuk variabel prestasi kerja sebesar 0,457, hal ini menunjukkan bahwa setiap kenaikan 1
$\%$ faktor prestasi kerja maka akan meningkatkan kinerja sebesar 45,7\%.

\subsection{Uji F (Simultan)}

Uji $F$ merupakan suatu pengujian untuk mengetahui pengaruh variabel bebas terhadap variabel terikat secara simultan. Dari tabel tabel 5.16 berikut ini, diperoleh nilai Fhitung sebesar 17,752. Dengan menggunakan confidence interval (CI) $95 \%$ df 3:67 ( $\mathrm{a}=0.05)$ dari tabel distribusi $\mathrm{F}$ diperoleh nilai 2, 74. Dengan demikian Fhitung > Ftabel $(17,752>2,74)$ maka $\mathrm{H}_{0}$ ditolak dan $\mathrm{H}$ diterima, artinya secara bersama-sama (simultan) variabel kepuasan kerja, kualitas kehidupan kerja dan prestasi kerja sebagai variabel bebas berpengaruh terhadap kinerja sebagai variabel terikat di Mts Al Jamiyatul Wasliyah Tembung.

Tabel 5. Hasil Uji Simultan ANOVA $^{\mathrm{a}}$

\begin{tabular}{|ll|l|l|l|l|l|}
\hline Model & & $\begin{array}{l}\text { Sum } \\
\text { Squares }\end{array}$ & of df & Mean Square & F & Sig. \\
\hline \multirow{4}{*}{1} & Regression & 220.333 & 3 & 73.444 & 17.752 & $.000^{\mathrm{b}}$ \\
& Residual & 260.652 & 63 & 4.137 & & \\
\hline & Total & 480.985 & 66 & & & \\
\hline
\end{tabular}

a. Dependent Variable: Kinerja

b. Predictors: (Constant), Prestasi, Kualitas, Kepuasan

Pada tabel tabel 5 di atas terlihat nilai signifikansi $\mathrm{O}, \mathrm{OOOb}<0.05$, hal ini berarti bahwa secara bersarna-sama (simultan) kepuasan kerja, kualitas kehidupan kerja dan prestasi kerja sebagai variabel bebas memiliki pengaruh yang sangat signifikan (highly significant) terhadap kinerja sebagai variabel terikat di Mts Al Jamiyatul Wasliyah Tembung.

\subsection{Uji t (Parsial)}

Uji $t$ merupakan suatu pengujian untuk mengetahui pengaruh variabel be bas terhadap variabel terikat secara parsial. Dari tabel 5.17 berikut ini diperoleh nilai

thitung masing-rnasing variabel. Nilai thitung tersebut selanjutnya dibandingkan dengan nilai t1abe1 pada tingkat kepercayaan $95 \%$ atau a $=0,05$. Nilai t1abe1 pada df 3:67 dengan $a=0,05$ dari tabel distribusi $\mathrm{t}$ diperoleh nilai 1,996.

Pengaruh parsial dari variabel kepuasan kerja diperoleh nilai thitung 2,753, dengan demikian thitung > t1abeI $(2,753>1,996)$ dan nilai signifikan $0,008<0.05$, maka Ho ditolak dan $\mathrm{H}$, diterima, yang berarti bahwa variabel kepuasan kerja berpengaruh positif dan signifikan terhadap kinerja guru di Mts Al Jamiyatul

Coefficients $^{\mathrm{a}}$

Tabel 6. Hasil Uji Parsial

\begin{tabular}{|ll|l|l|l|l|l|}
\hline \multicolumn{2}{|l|}{ Model } & \multicolumn{2}{|l|}{ Unstandardized Coefficients } & $\begin{array}{l}\text { Standardized } \\
\text { Coefficients }\end{array}$ & T & Sig. \\
\cline { 3 - 5 } & & B & Std. Error & Beta & & \\
\hline \multirow{4}{*}{1} & (Constant) & 4.163 & 4.577 & & .909 & .367 \\
& Kepuasan & .271 & .098 & .271 & 2.753 & .008 \\
& Kualitas & .283 & .135 & .197 & 2.101 & .040 \\
& Prestasi & .457 & .094 & .481 & 4.836 & .000 \\
\hline
\end{tabular}

a. Dependent Variable: Kinerja 
Berdasarkan tabel 6 diatas diketahui bahwa nilai koefisien regresi yang paling tinggi adalah prestasi kerja sebesar 0,481 atau $48,1 \%$. Hal ini berarti bahwa prestasi kerja berpengaruh lebih dominan terhadap kinerja guru di Mts Al Jamiyatul Wasliyah Tembung.

\subsection{Koefisien Determinasi}

Pada tebel 7 dibawah ini diperoleh nilai koefisien determinasi (R2) sebesar 0,458, berarti bahwa terhadap kinerja guru di Mts Al Jamiyatul Wasliyah Tembung dapat dijelaskan oleh perubahan kepuasan kerja, kualitas kehidupan kerja dan prestasi kerja sebesar $45,8 \%$, sedangkan sisanya sebesar $54,2 \%$ dipengaruhi oleh variabel lain yang tidak dianalisis dalam penelitian ini.

Model Summary ${ }^{\mathrm{b}}$

Tabel 7. Koefisien Determinasi

\begin{tabular}{|l|l|l|l|l|}
\hline Model & $\mathrm{R}$ & $\mathrm{R}$ Square & $\begin{array}{l}\text { Adjusted R } \\
\text { Square }\end{array}$ & $\begin{array}{l}\text { Std. Error of } \\
\text { the Estimate }\end{array}$ \\
\hline 1 & $.677^{\mathrm{a}}$ & .458 & .432 & 2.034 \\
\hline
\end{tabular}

a. Predictors: (Constant), Prestasi, Kualitas, Kepuasan

b. Dependent Variable: Kinerja

\section{Pembahasan}

4.1. Pengaruh

Terhadap

Kepuasan

Kerja

Al Jamiyatul Wasliyah Tembung

Berdasarkan basil pengujian dapat disimpulkan bahwa kepuasan kerja berpengaruh signifikan terhadap kinerja guru di Mts Al Jamiyatul Wasliyah Tembung yang ditunjukkan pada basil penelitian 1hitung > tlabel $(2,753>1,996)$ dan nilai signifikan sebesar $0,008<0.05$. Dalam persamaan regresi diperoleh basil $\mathrm{Y}=4,163+0,271 \mathrm{X},+0,283 \mathrm{X} 2+0,457 \mathrm{X} 3+£ \quad$ yang berarti bahwa kepuasan kerja mempunyai pengaruh yang positif terhadap kinerja guru di Mts Al Jamiyatul Wasliyah Tembung, sehingga dapat dinyatakan setiap kenaikan $1 \%$ faktor kepuasan kerja maka akan meningkatkan kinerja sebesar 27,1 \%, demikian sebaliknya setiap kepuasan kerja turun $1 \%$ maka kinerja akan ikut turun sebesar 27, $1 \%$. Hasil penelitian ini mendukung penelitian terdahulu sebelurnnya yang dilakukan oleh Enni Pudjiastuti, Untung Sriwidodo (2011), Febry Zakharia (2014) dan Samsul Arifin, Noer Aisyah Barlian, Zainul Hidayat (2018) yang menyatakan bahwa kepuasan kerja berpengaruh terhadap kinerja.

\subsection{Pengaruh Kualitas Kehidupan Kerja Terhadap Kinerja Guru Di Mts Al Jamiyatul Wasliyah Tembung}

Berdasarkan basil pengujian dapat disimpulkan bahwa kualitas kehidupan kerja berpengaruh signifikan terhadap kinerja guru di Mts Al Jamiyatul Wasliyah Tembung yang ditunjukkan pada basil penelitian thitung $>$ ttabel $(2,101>1,996)$ dan nilai signifikan sebesar $0,040<0.05$. Dalam persamaan regresi diperoleh basil $\mathrm{Y}=4,163+0,271 \mathrm{X},+0,283 \mathrm{X} 2+0,457 \mathrm{X} 3+£$

yang berarti bahwa kualitas kehidupan kerja mempunyai pengaruh yang positif terhadap kinerja guru di Mts Al Jamiyatul Wasliyah Tembung, sehingga dapat dinyatakan setiap kenaikan $1 \%$ faktor kualitas kehidupan kerja maka akan meningkatkan kinerja sebesar 28,3\%, demikian sebaliknya setiap kualitas kehidupan kerja turun 1\% maka kinerja akan ikut turun sebesar 28,3\%. Hasil penelitian ini mendukung penelitian terdahulu sebelurnnya yang dilakukan oleh Yudiar Alwan, Munandar, Wachid Fuady R (2017), dan Dessi Wahyu Hersanti, Gunistiyo, Dien Noviany Rahmatika (2020) yang menyatakan bahwa kualitas kehidupan kerja berpengaruh terhadap kinerja.

\subsection{Pengaruh Prestasi Kerja Terhadap Kinerja Guru Di Mts Al JamiyatulWasliyah Tembung}

Berdasarkan basil pengujian dapat disimpulkan bahwa prestasi kerja berpengaruh signifikan terhadap kinerja guru di Mts Al Jamiyatul Wasliyah Tembung yang ditunjukkan pada basil penelitian thitung > tabel $(4,836>1,996)$ dan nilai signifik:an sebesar $0,000<0.05$. Dalam persamaan regresi diperoleh hasil $Y=4,163+0,271 X,+0,283 X 2+0,457 X 3+£$ 
yang berarti bahwa prestasi kerja mempunyai pengaruh yang positif terhadap kinerja guru di Mts Al Jamiyatul Wasliyah Tembung, sehingga dapat dinyatak:an setiap kenaikan $1 \%$ fak:tor kualitas kehidupan kerja maka akan meningkatkan kinerja sebesar $45,7 \%$, demik:ian sebalik:nya setiap prestasi kerja turun $1 \%$ maka kinerja akan ik:ut turun sebesar $45,7 \%$. Hasil penelitian ini mendukung penelitian terdahulu sebelumnya yang dilakukan oleh Annierah Maulana Usop, Doctor Kamarulzaman Askandar, Maeda Langguyuan-Kadtong, Datu Amir Sajid, Onotan Usop (2013), dan Samsul Arifin, Noer Aisyah Barlian, Zainul Hidayat (2018) yang menyatakan bahwa prestasi kerja berpengaruh terhadap kinerja.

\subsection{Pengaruh Kepuasan Kerja Kualitas Kehidupan Kerja Dan Prestasi Kerja Terhadap Kinerja Guru Di Mts Al Jamiyatul Wasliyah Ternbung}

Berdasarkan basil pengujian dapat disimpulkan bahwa kepuasan kerja, kualitas kehidupan kerja dan prestasi kerja secara bersama-sama (simultan) berpengaruh signifikan terhadap k:inerja guru di Mts Al Jamiyatul Wasliyah Tembung yang ditunjuk:kan pada basil penelitian F11itung > FtabeI (17,752> 2,74) dan nilai signifik:an sebesar $\mathrm{O}, \mathrm{OOOb}$ $<0.05$.

Berdasarkan hasil penyebaran kuesioner diketahui secara rata-rata jawaban responden atas indikatorindikator variabel kepuasan kerja adalah $67,7 \%$ menyatakan setuju dan respon tertinggi terdapat pada butir pernyataan nomor 8 yang menyatakan bahwa "Saya senang dengan pekerjaan yang menarik dan menantang". Berarti bahwa suatu kepuasan bagi guru jika ia mampu menyelesaikan pekerjaan yang menarik dan menantang yang pada akhirnya dapat pula mempengaruhi kinerja guru tersebut. Selanjutnya rata-rata jawaban responden atas indikator-indikator variabel kualitas kehidupan kerja adalah 53, $1 \%$ menyatakan setuju dan respon tertinggi terdapat pada butir pernyataan nomor 4 yang menyatakan bahwa "Gaji yang diberikan dapat menyejahterakan kehidupan saya". Berarti bahwa guru menyatakan bahwa gaji merupakan tolok ukur kesejahteraan guru yang pada akhirnya berakibat meningkatnya kinerja guru.

Selanjutnya rata-rata jawaban responden atas indikator-indikator variabel prestasi kerja adalah 54, 7\% menyatakan setuju dan respon tertinggi terdapat pada butir pernyataan nomor 1 yang menyatakan bahwa "Pegawai selalu teliti dalam melaksanakan pekerjaan yang diberikan". Berarti bahwa guru yang teliti dalam melakukan pekerjaan merupakan salah satu indikator baiknya kinerja guru tersebut.

\section{Kesimpulan}

Dari basil analisis yang telah dibahas, maka ditarik kesimpulan sebagai berikut:

1) Kepuasan kerja berpengaruh positif dan signifikan terhadap kinerja guru di Mts Al Jamiyatul Wasliyah Tembung.

2) Kualitas kehidupan kerja berpengaruh positif dan signifikan terhadap kinerja guru Di Mts Al Jamiyatul Wasliyah Tembung.

3) Prestasi kerja berpengaruh positif dan signifikan terhadap kinerja guru di Mts $\mathrm{Al}$ Jamiyatul Wasliyah Tembung

4) Kepuasan kerja, kualitas kehidupan kerja dan prestasi kerja berpengaruh signifikan terhadap kinerja guru di Mts Al Jamiyatul Wasliyah Tembung Wasliyah Tembung.

\section{DAFTAR PUSTAKA}

A. Anwar Prabu Mangkunegara 2012. Manajemen Sumber Daya Manusia. Bandung: PT. Remaja Rosdakarya.

A. Anwar Prabu Mangkunegara 2011. Manajemen Sumber Daya Manusia. Bandung: PT. Remaja Rosdakarya.

A. Anwar Prabu Mangkunegara, 2013. Manajemen Sumber Daya Manusia. Bandung: PT. Remaja Rosdakarya.

Annierah Maulana Usop, Doctor Kamarulzaman Askandar, Maeda Langguyuan Kadtong, Datu Amir Sajid Onotan Usop, Work Performance And Job Satisfaction Among Teachers, International Journal of Humanities and Social Science Vol. 3 No. 5; March 2013.

Ardy Novianto, "Analysis Faktor-Faktor Kualitas Kehidupan Kerja sebagai Pendukung Peningkatan Keterikatan Karyawan pada PT Taspen 
(PERSERO) Cabang Bogar", (Skripsi, IPB, Bogar, 2012), h.13

Arikunto, S. (2013). Prosedur Penelitian Suatu Pendekatan Praktik. Jakarta: Rineka Cipta.

Arikunto, S. (2013). Prosedur Penelitian Suatu Pendekatan Praktik. Jakarta: Rineka Cipta.

Arikunto, Suharsimi. (2009). Dasar-dasar Evaluasi Pendidikan. Jakarta:Bumi Aksara.

As'ad, Mohammad, Kepemimpinan efektif dalam Perusahaan, Suatu Pendekatan Psikologik. Edisi Kedua. Yogyakarta: Liberty

Azwar. Saifuddin. 2013. Metode Penelitian. Yogyakarta: Pustaka Pelajar.

Charitin Devi, Ropal Tores, Hilda Wahyuni, "Pengaruh Kepuasan Kerja Terhadap Prestasi Kerja Pegawai Pada Dinas Tenaga Kerja Dan Transmigrasi Kabupaten Musi Banyuasin", Adminika Volume 4 No. I (Januari-Juni) 2018

Cherrington, David J. 2010. The Management of Human Resources (4thEdition). New Jersey: Prentice Hall Inc.

Davis, Keith. 2010. Organizational Behavior-Human Behavior at Work $13^{\text {th }}$ Edition. New Delhi: Mcgraw Hill Company.

Departemen Pendidikan Nasional, 2005 Undang-Undang Nomor 14 Tahun 2005, Tentang Guru dan Dosen, Jakarta: Depdiknas.

Departemen Pendidikan Nasional. 2008. Pengembangan Bahan Ajar dan Media. Jakarta: Departemen Pendidikan Nasional

Depdiknas. 2009. Buku 3 Pedoman Penyusunan Portofolio. Direktorat Jendral Pendidik:an Tinggi

Dessi Wahyu Hersanti, Gunistiyo, Dien Noviany Rahmatika, Analisis Pengaruh Quality Of Work Life, Motivasi Berprestasi Dan Kepemimpinan Transformasional Terhadap Kinerja Guru, Jumal Inovasi Pembelajaran Karakter (JIPK)Vol. 5, No. 1, Januari-April 2020.

Dimyati, H., \& Nurjaman, K. (2014). Manajemen Proyek.Bandung: CV Pustaka Setia.

Dwi Astrid Avianti, Lindawati Kartika, "Analisis Quality of Work Life pada Generasi X dan Y Alumni Fakultas Ekonomi dan Manajemant," Jurnal Riset
Managemant dan Bisnis (JRMB) Fakultas Ekonomi UNIAT Vol.2, No.2 (Juni 2017): 7.

E. Lawler, Edward 2011. Global Trends in Human Resource Management: A TwentyYear Analysis, StanfordBusiness Books, London.

Edy Sutrisno. 2010. Manajemen Sumber Daya Manusia. Edisi Pertama. Cetakan Pertama. Jakarta: Penerbit Kencana.

Enni Pudjiastuti, Untung Sriwidodo, Pengaruh Kompetensi, Disiplin Kerja, Dan Kepuasan Kerja Terhadap Kinerja Smp Negeri 1 Purwodadi Grobogan, Jumal Manajemen Sumberdaya Manusia Vol. 5 No. 2 Desember 2011: 120-131

Fabian Michele Paseki, "Kualitas Kehidupan Kerja dan Kinerja Karyawan Terhadap Pengembangan Karir pada Kanwil Direktorat Jenderal Kekayaan Negara Sulutenggo Malut di Manado,"Jurnal EMBA Vol.1, No.4 (Desember 2013): 1242.

Febry Zakharia, Pengaruh Budaya Organisasi Dan Kepuasan Kerja Terhadap Kinerja Guru Smp Yadik:a 3 Tangerang, Jurnal Ilmu Ekonomi dan Sosial, Jilid 3, Nomor 1, Juli 2014, hlm. 39 - 50.

Gaol, CHR. Jimmy L, 2014. A to Z Human Capital (Manajemen Sumber Daya Manusia) Konsep, Teori, dan Pengembangan dalam Konteks Organisasi Publik dan Bisnis, PT. Gramedia Widiasarana, Jakarta.

Hary Murti dan Veronika Agustini Srimulyani, 2013. Pengaruh Motivasi Terhadap Kinerja Pegawai Dengan Variabel Pemediasi Kepuasaan Kerja Pada PDAM Kota Madiun. Jurnal Riset Manajemen dan Akuntansi (JRMA). Vol. 1 No. 1, Februari 2013. pp. 10-17.

Hasibuan, Malayu S.P. 2016. Manajemen Sumber Daya Manusia. Jakarta: PT Bumi Aksara.

Hasibuan, Malayu S.P., 2011. Manajemen Sumber Daya Manusia Bumi Aksara, Jakarta.

Ivancevich, J.M., dan Matteson, M. T (2010). Organizational Behaviour and Management. Singapore: Irwin/McGrawhill.

Kaplan, M Robert dan Saccuzzo, Dennis P. 2012. Pengukuran Psikologi: Prinsip,penerapan, dan Isu. Salemba Humanika: Jakarta 
Kreitner, Robert dan Angelo Kinicki. (2014). Perilaku Organisasi. Jakarta: Salemba Empat.

Luthans, Fred. 2012. "Perilaku Organisasi". Yogyakarta: Penerbit Andi. Mangkuprawira, 2012, Manajemen Sumber Daya Manusia Strategik, Jakarta.

Marihot Tua Effendi Hariandja, Managemant Sumber Daya Manusia Pengadaan, Pengembangan, Pengkompensasian dan Peningkatan Produktivitas Pegawai, (Jakarta: PT Gramedia Widiasarana Indonesi, 2012), h. 292

Milton, Friedman. (2010). The Social Responsibility of Business is to Increase its Profits. USA: The New York Time Company.

Nana Sudjana 2010. Dasar-dasar Proses Belajar, Sinar Baru Bandung

Noor Arifin, Analisis Kualitas Kihidupan Kerja, Kinerja dan Kepuasan Kerja Pada CV Duta seneran Jepara, Jurnal Economia, Vol. 8 No. 1 April 2012, hlm. 12.

Peraturan Menteri Negara Pendayagunaan Aparatur Negara dan Reformasi Birokrasi Nomor 16 Tahun 2009 tentang Jabatan Fungsional Guru Dan Angka Kreditnya.

Priansa, D. J. (2010). Perencanaan \& Pengembangan SDM. Bandung: Alfabeta. Priansa, D. J. (2016). Perencanaan \& Pengembangan SDM. Bandung: Alfabeta.

Rivai, Veithzal 2010. Manajemen Sumber Daya Manusia untuk Perusahaan dari Teori ke Praktik.Jakarta: PT. Raja Grafindo

Robbins, Stephen P. \& Judge, Timothy A., 2013, Perilaku Organisasi, buku 2. Jakarta: Salemba Empat.

Robbins, Stephen P. dan Coulter, Mary 2010. Manajemen Edisi Kesepuluh Jakarta: penerbit Erlangga

S Anugrahini Irawati, "Kualitas Kehidupan Kerja terhadap Kinerja Pegawai Dinas Prindustrian dan Perdagangan Kabupaten Sampang,"Jurnal Neo-BisVol.9, No.2 (Desember 2015): 42

Samsul Arifin, Noer Aisyah Barlian, Zainul Hidayat, Pengaruh Motivasi, Prestasi, Dan Kepuasan Kerja Terhadap Kinerja Karyawan Puskesmas Sumbersari Kecamatan Rowokangkung Kabupaten Lumajang, Progress Conference vol.I, No.I, Agustus 2018 E-ISSN 2622-304X, P-ISSN: 2622-3031
Siagian, 2013, Manajemen Sumber daya Manusia, Bumi aksara, jakarta.

Sugiyono. 2010. Metode Penelitian Pendidikan Pendekatan Kuantitatif, kualitatif, dan R\&D. Bandung: Alfabeta.

Suparlan.(2011).Tanya Jawab Pengembangan Kurukulum dan Materi Pembelajaran. Jakarta: PT. Bumi Aksara

Supranto, 2001, Pengukuran Tingkat Kepuasan Pelanggan untuk Menaikkan Pangsa Pasar, Penerbit Rineka Cipta, Jakarta, 230,243

Wirawan, Dr. 2015. Manajemen Sumber Daya Manusia Indonesia.Jakarta : PT. Rajagrafindo Persada. Cetakan kesatu Maret.

Yamin, Martinis dan Maisah. 2010. Standarisasi Kinerja Guru. Jakarta: Persada Press.

Yudiar Alwan, Munandar, Wachid Fuady R, Pengaruh Kualitas Kehidupan Kerja Dan Komitmen Organisasional Terhadap Kinerja Tenaga Pendidik Dengan Kepemimpinan Transformasional Sebagai Variabel Moderasi, Jumal Ekonomi Manajemen dan Akuntansi No. 43 I Th. XXIV I Oktober 2017. 